\title{
Panel of Referees
}

\section{Eva Johansson}

(C) Springer Science+Business Media B.V. 2011

The editorial board wishes to thank the following colleagues who have assisted them as editorial referees during 2010.

Madeleine Baillargeon OMEP vice president, North America and Caribbean

Inger Berntsson University of Gothenburg, Sweden

Susan Danby Queensland University of Technology, Australia

Brownyn Davies University of Melbourne, Australia

Agnès Florin Université de Nantes, France

Eva Gannerud University of Gothenburg, Sweden

Sue Grieshaber Queensland University of Technology, Australia

Gil Meyer Haute école de travail social et de la santé EESP Lausanne, Switzerland

Sue Walker Queensland University of Technology, Australia

Tim Waller University of Wolverhampton, United Kingdom

Jayne White Victoria University of Wellington, New Zealand

Julie Davies Queensland University of Technology, Australia

The IJEC Editorial board, and the Guest editor of IJEC 42:2 Professor Jan-Erik Johansson especially, wishes to acknowledge all reviewers of the special issue for their excellent work.

E. Johansson $(\bowtie)$

Department of Early Childhood Education, Faculty of Arts and Education, University of Stavanger,

4036 Stavanger, Norway

e-mail: eva.johansson@uis.no 